Cite this: New J. Chem., 2014, 38,1225

Received (in Montpellier, France) 9th August 2013,

Accepted 7th January 2014

DOI: 10.1039/c3nj00910f

www.rsc.org/njc

\section{Luminescence behaviour in acetonitrile and in the solid state of a series of lanthanide complexes with a single helical ligand $\$$}

\author{
Miki Hasegawa, ${ }^{\star a}$ Hideki Ohtsu, ${ }^{\text {ab }}$ Daisuke Kodama, ${ }^{a}$ Takeshi Kasai, ${ }^{a}$ Shoya Sakurai, ${ }^{a}$ \\ Ayumi Ishii ${ }^{a}$ and Kengo Suzuki ${ }^{c}$
}

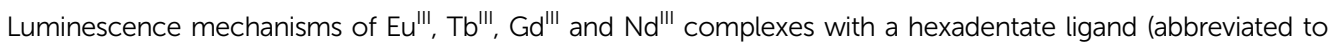
EuL, TbL, GdL, and NdL, respectively), which have two bipyridine moieties bridged by an ethylenediamine unit, have been examined. Our molecular design is that each complex forms a single helical polar structure based on the chelate ring to retain solubility in solutions. EuL and NdL show comparably bright emission from $\mathrm{ff}$ transitions both in acetonitrile solution and in the solid state. To understand the mechanism of the emission in detail, the energy level of the triplet $(T)$ state of the ligand $L$ has been estimated based on the phosphorescence measurements of GdL, because Gd'll shows no ff emission. The donor level of the T state of $\mathbf{L}$ and the acceptor level of Eu $u^{\prime \prime \prime}$ or $\mathrm{Nd}^{\prime \prime \prime}$ can overlap, indicating that the excited photon localized on $\mathbf{L}$ has been used for the efficient ff emission, while not for $\pi \pi^{\star}$ emission. For TbL, the luminescence quantum yield is significantly dependent on temperature and the state: in the solid state of $\mathrm{TbL}$, the quantum yield of $\mathrm{ff}$ emission is over $90 \%$ at $77 \mathrm{~K}$, while no luminescence is observed at room temperature, and in solution TbL shows no emission. This observation suggests that the emissive $\mathrm{f}$-level of $\mathrm{Tb}^{\mathrm{III}}$ and the energy donor level of the excited $T$ state of $\mathbf{L}$ are in thermal equilibrium. The described lanthanide complexes are stable and retain their molecular structure even in solutions and show characteristic luminescence behaviour based on the energy relaxation process of each lanthanide ion. Furthermore the HollI complex with $\mathbf{L}(\mathrm{HoL})$ has been prepared and its structure has been analyzed. HoL has a twisted arrangement of the bipyridine moiety surrounding $\mathrm{Ho}^{\text {III }}$ due to the small ionic radius of $\mathrm{Ho}^{\text {III. }}$

\section{Introduction}

Highly luminescent lanthanide (Ln) complexes have attracted much attention because they are applied to functional materials such as OLEDs, ${ }^{1-6}$ solar cell systems, ${ }^{7,8}$ and sensors in solutions. ${ }^{9-13}$ Recently, intensive work has focused on the Ln complexes with organic ligands which exhibit significant luminescent properties. ${ }^{14,15}$

\footnotetext{
${ }^{a}$ College of Science and Engineering, Aoyama Gakuin University, 5-10-1 Fuchinobe, Chuo-ku, Sagamihara, Kanagawa 252-5258, Japan.

E-mail: hasemiki@chem.aoyama.ac.jp; Fax: +81-42-759-6221

${ }^{b}$ Graduate School of Science and Engineering, University of Toyama, 3190 Gofuku, Toyama, Toyama 930-8555, Japan

${ }^{c}$ Hamamatsu Photonics K. K., 812 Joko-cho, Higashi-ku, Hamamatsu, Shizuoka 341-3196, Japan

$\dagger$ Dedicated to Dr Toshihiko Hoshi, Professor Emeritus from Aoyama Gakuin University, on the occasion of his 77th birthday.

¥ Electronic supplementary information (ESI) available: Detailed preparation and characterization of the complexes. CCDC 919427-919431 (a series of lanthanide complexes with $\mathbf{L}$ ). Electronic absorption spectra of $\mathbf{N d} \mathbf{L}$ and $\mathrm{HoL}$, excitation spectra, luminescence decay curves, and representation of energy transfer mechanisms of the complexes. For ESI and crystallographic data in CIF or other electronic format see DOI: 10.1039/c3nj00910f
}

The spectral feature of their luminescence originating from ff-electronic transitions of Ln complexes, generally, is specifically compared with that of fluorescence or phosphorescence of neat organic compounds; ${ }^{16,17}$ the ff emission of the Ln ion appears as narrow bands because of the inner-core transitions being shielded from the outer-sphere, and has been induced by the photo-excitation of $\pi$-electronic systems of the organic ligand moieties via an intramolecular energy transfer. ${ }^{18-21}$ In other words, for these Ln complexes, the $\pi$-electronic moieties of the ligands act as photo-antennae and as energy donors, and a splitter of the f-level of $\mathrm{Ln}^{\mathrm{III}}$ as an acceptor in the complexes. The energy differences between the energy donor and the acceptor based on molecular design affect directly the efficiency of ff-emissions. For instance, there are a number of papers that describe Ln complexes with an organic ligand showing over $50 \%$ or $100 \%$ efficiency in the luminescence. ${ }^{16}$

These ligands also exert structural effects on the properties of the Ln complexes. For instance, such structural modifications lead to the tuning of luminescence efficiency and the band appearances of the $\mathrm{ff}$ emission. ${ }^{22-26}$ Moreover, the enhanced $\mathrm{ff}$ emission may be induced, if the ligands act as a shield from the 


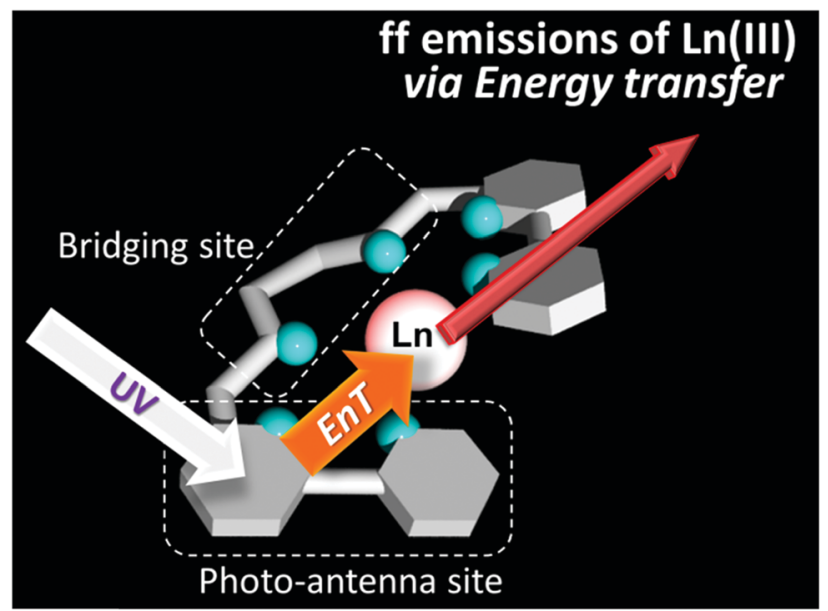

Fig. 1 Strategy to design a helical molecular structure that retains a strong dipole moment to induce the ff-emission of Ln complexes. In this figure, EnT means the intramolecular energy transfer.

outer-sphere with a stable structure in solution ${ }^{23,27-30}$ or in the solid state. ${ }^{24,31-35}$

A chelate effect provides a fundamental but most useful technique to design stable metal complexes, and the coordination number of the chelate ring contributes to the stability constant of the coordination in solution. There are some manuscripts for metal complexes, e.g. $\mathrm{Co}, \mathrm{Cu}, \mathrm{Fe}, \mathrm{Zn}, \mathrm{Ag}, \mathrm{Eu}$ ions, with a hexadentate ligand forming the helicate molecular structure. ${ }^{36-38}$ It is well known that Constable and Tocher et al. reported various metal complexes having d- or f-block ions with a helicate of a polypyridyl ligand. In their evolution of the molecular preparation, ${ }^{38}$ for instance, six pyridine moieties in the ligand were demonstrated to have the ability to form a single-helical structure by coordinating with a Eu ion.
Our approach is to understand the emission mechanism of a series of lanthanide ( $\mathrm{Eu}, \mathrm{Gd}, \mathrm{Tb}$, and $\mathrm{Nd}$ ) complexes, in view of photochemistry to realize the efficient luminescent principle in the solid state and in solution. In this strategy, we designed a new hexadentate ligand to wind the Ln ion, and the formed complex would retain the strong dipole moment to dissolve into solution with emitting ability (Fig. 1). The target complexes would have five pentagonal-chelate-rings in a molecule to retain their stability in solution, the so called chelate effect. It is expected that the molecular structure with the organic ligand would form a co-planar structure, and both sides of the structure would give two exchangeable/ flexible sites.

In the present study, electronic transitions of a series of new Ln complexes (abbreviated to LnL, $\mathrm{Ln}=\mathrm{Nd}, \mathrm{Eu}, \mathrm{Gd}, \mathrm{Tb}$ and $\mathrm{Ho}$ shown in Fig. 2) have been discussed. In particular, we have focused on the emission properties of the $\mathrm{Eu}$ and $\mathrm{Tb}$ complexes both in solution and the solid state. Here, we use a hexadentate ligand $\mathbf{L}$ having two bipyridine (abbreviated to bpy) moieties bridged by an ethylenediamine unit (abbreviated to en) designed based on the above strategy. Two bpy moieties may also act as photo-antennae to transport the excitation energy for the Ln excitation. The en group prevents conjugation of two bpy in LnL, and the excited state of the $\pi$ electronic system of the bpy can be treated as the same as those of simple bpy derivatives. The X-ray structural analysis of a series of $\operatorname{LnL}(\mathrm{Ln}=\mathrm{Nd}, \mathrm{Eu}, \mathrm{Gd}, \mathrm{Tb}$ and Ho) complexes was also performed to support spectral discussion concerning the molecular structure.

\section{Results and discussion}

\section{Structural analyses}

We have thus synthesized a new ligand $\mathbf{L}$ containing two bpy moieties and a series of $\mathrm{LnL}(\mathrm{Nd}, \mathrm{Eu}, \mathrm{Gd}, \mathrm{Tb}$ and Ho complexes (a)

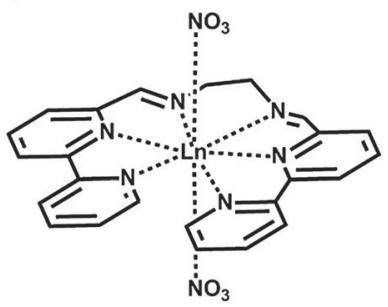

(b)

Side view

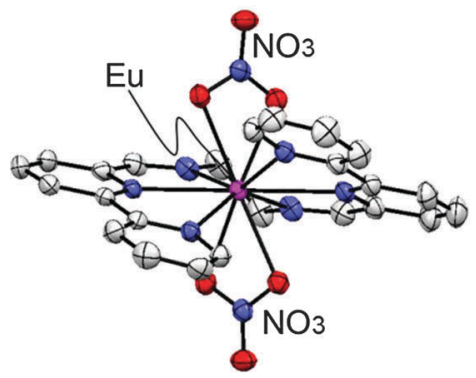

Top view

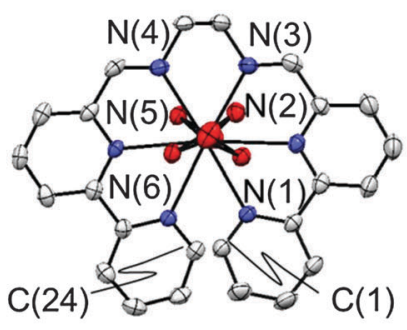

(c)

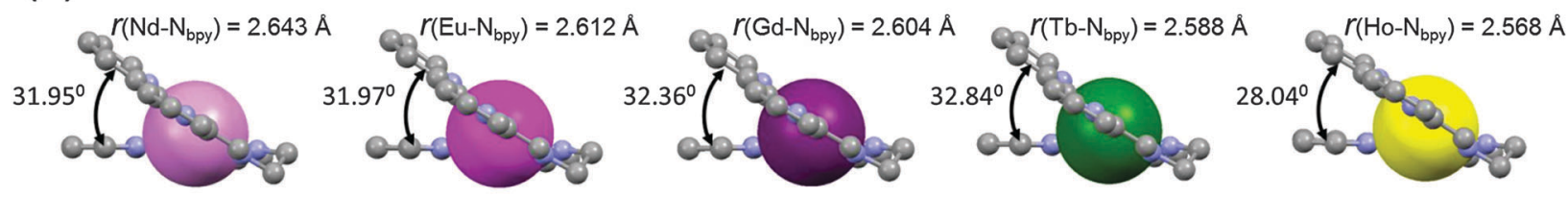

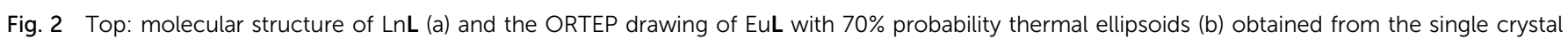

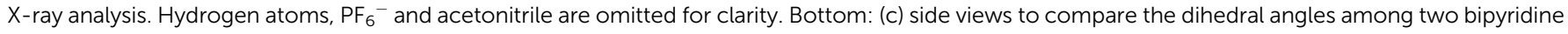

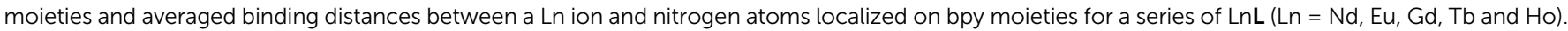

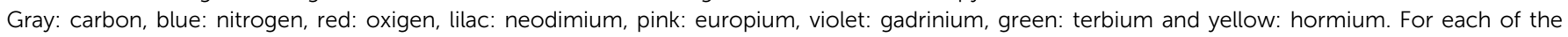
illustrations, $\mathrm{LnL}$ has no $\mathrm{NO}_{3}{ }^{-}$for clarity. 
with $\mathbf{L}$ are abbreviated to $\mathrm{Nd} \mathbf{L}, \operatorname{EuL}, \operatorname{Gd} \mathbf{L}, \mathrm{TbL}$ and $\mathrm{HoL}$, respectively).

The single crystal structures of LnL have been determined by the single crystal X-ray diffraction analyses. Fig. 2 and Fig. S3 (ESI $\ddagger$ ) show the molecular structure of EuL and the comparison of those of NdL, GdL, TbL and HoL. In EuL, six nitrogen atoms of $\mathbf{L}$ coordinate to the centre metal $\mathrm{Eu}$, and form five pentagonalchelate rings equatorially. Each bpy moiety keeps coplanar, and two terminated-pyridine rings take the face-to-face conformation each other in a van der Waals distance, $r(\mathrm{C}(1)-\mathrm{C}(24))=3.178 \AA$ in EuL. Furthermore, two nitrate anions bind to the Eu from both apical sites, and the Eu ion has a total coordination number of ten. From the comparison of the molecular shape of a series of $\mathrm{LnL}(\mathrm{Ln}=\mathrm{Nd}, \mathrm{Eu}, \mathrm{Gd}, \mathrm{Tb}$ and Ho), it is found that $\mathbf{L}$ can form the same molecular structure with other Ln ions (Fig. S3, ESI $\$$ and Table 1). These metal ions are in the order corresponding to the ionic radii and atomic number, i.e., the ionic radius of $\mathrm{Nd}^{\mathrm{III}}$ is larger than that of $\mathrm{Ho}^{\mathrm{III}}$ known as the lanthanide contraction. The interatomic distance shows the average value of four $\mathrm{Ln}-\mathrm{N}_{\mathrm{bpy}}$ distances, $r\left(\mathrm{Ln}-\mathrm{N}_{\mathrm{bpy}}\right)$, of each complex (Tables S1 and S2, ESI $\left.\$\right)$. It is worth noting that the lanthanide contraction affects the length of $\mathrm{Ln}-\mathrm{N}_{\mathrm{bpy}}$ bonding and the distance of the terminal pyridyl group in the bpy skeleton based on the periodicity of Ln ionic radii. The dihedral angle among two bpy moieties of the complex increases periodically with increasing atomic numbers. It is reflected in their electronic repulsion among the terminal pyridyl group in the bpy skeleton, due to the changes in distances of the $\mathrm{Ln}-\mathrm{N}_{\mathrm{bpy}}$ bonding. In the case of HoL, the dihedral angle does not show periodicity, because of the distortion of bpy skeletons.

In a unit cell of EuL, there are two molecules having chiralities; a right- and a left-handed isomer (Fig. 3(a)). A couple of hexafluorophosphate and acetonitrile is also included in the unit cell of EuL (Fig. S4(a), ESI ). As shown in Fig. 3(b), the molecular packing of EuL suggests that two isomers between the neighboring unit cells interact through the intermolecular $\pi \pi$ interaction of their bpy skeletons at the distance of 3.59-3.83 A. This interaction results in the formation of their independent column-like structure as shown in Fig. S4(b) and (c) (ESI + ), which is supported by the existence of $\mathrm{PF}_{6}{ }^{-}$ions and acetonitrile molecules.

$\mathrm{X}$-ray structure analysis reveals that all complexes are isostructural with each lanthanide counterpart, and the $\mathrm{Nd}, \mathrm{Eu}$, $\mathrm{Gd}$, and $\mathrm{Tb}$ complexes are isomorphous with each other. Remarkably, the detailed crystallographic analysis clarified the void spaces in these complexes, which are placed around the inversion centre of the unit cell as shown in Fig. S5 and Table S3 (ESI $\$$ ), originating from the desolvation of one acetonitrile. This means that 1.5 acetonitrile molecules were in an asymmetric unit and totally three acetonitrile molecules were in the unit cell before desolvation occurred. In this case, the space group of the initial crystal should have lower symmetry, $P 1$, compared to that of the desolvated crystal, $P \overline{1}$, because acetonitrile is not a symmetric molecule. The channel structure of the solvents makes it possible to desolvate easily from the crystal.

Among those complexes, HoL is the only one complex that has two molecules of acetonitrile in an asymmetric unit, meaning that there are totally four acetonitrile molecules in a unit cell.

\section{Luminescence properties of $\mathrm{LnL}$}

To discuss the luminescence spectra of $\mathbf{L n L}$, the electronic absorption spectra should be observed, because they generally give much information on the electronic and molecular structure. Fig. 4 shows the electronic spectra localized on the ligand moieties of EuL, GdL and TbL in the solid state and in acetonitrile. All complexes LnL show the $\pi \pi^{*}$ absorption bands of the ligand mainly at 280, 305 and $330 \mathrm{~nm}$ in the solid state. Their corresponding

Table 1 Crystallographic data for $\mathrm{LnL}$

\begin{tabular}{|c|c|c|c|c|c|}
\hline Ln & $\mathrm{Nd}$ & $\mathrm{Eu}$ & $\mathrm{Gd}$ & $\mathrm{Tb}$ & Ho \\
\hline Formula & $\mathrm{C}_{26} \mathrm{H}_{23} \mathrm{~F}_{6} \mathrm{~N}_{9} \mathrm{NdO}_{6} \mathrm{P}$ & $\mathrm{C}_{26} \mathrm{H}_{23} \mathrm{EuF}_{6} \mathrm{~N}_{9} \mathrm{O}_{6} \mathrm{P}$ & $\mathrm{C}_{26} \mathrm{H}_{23} \mathrm{~F}_{6} \mathrm{GdN}_{9} \mathrm{O}_{6} \mathrm{P}$ & $\mathrm{C}_{26} \mathrm{H}_{23} \mathrm{~F}_{6} \mathrm{~N}_{9} \mathrm{O}_{6} \mathrm{PTb}$ & $\mathrm{C}_{28} \mathrm{H}_{26} \mathrm{~F}_{6} \mathrm{HoN}_{10} \mathrm{O}_{6} \mathrm{P}$ \\
\hline Formula weight & 846.74 & 854.46 & 859.75 & 861.42 & 908.49 \\
\hline Crystal size (mm) & $0.13 \times 0.09 \times 0.02$ & $0.15 \times 0.11 \times 0.08$ & $0.18 \times 0.16 \times 0.10$ & $0.22 \times 0.10 \times 0.08$ & $0.13 \times 0.09 \times 0.02$ \\
\hline Crystal system & Triclinic & Triclinic & Triclinic & Triclinic & Triclinic \\
\hline Space group & $P \overline{1}$ & $P \overline{1}$ & $P \overline{1}$ & $P \overline{1}$ & $P \overline{1}$ \\
\hline$a(\AA)$ & $8.949(2)$ & 8.9999(9) & $9.0151(7)$ & $9.0172(11)$ & $9.961(3)$ \\
\hline$b(\AA)$ & $12.231(3)$ & $12.2528(12)$ & $12.2140(9)$ & $12.2389(15)$ & $13.593(4)$ \\
\hline$c(\AA)$ & $16.394(4)$ & $16.2526(16)$ & $16.1835(12)$ & $16.133(2)$ & $13.751(4)$ \\
\hline$\alpha\left({ }^{\circ}\right)$ & $112.158(2)$ & $112.3060(10)$ & $112.0360(10)$ & $112.0540(10)$ & $68.307(3)$ \\
\hline$\beta\left(^{\circ}\right)$ & $104.132(2)$ & $104.4460(10)$ & $104.2970(10)$ & $104.2690(10)$ & $86.035(3)$ \\
\hline$\gamma\left({ }^{\circ}\right)$ & $92.428(3)$ & $91.8160(10)$ & $91.8260(10)$ & $91.6220(10)$ & $87.405(3)$ \\
\hline$V\left(\AA^{3}\right)$ & $1593.4(7)$ & $1589.6(3)$ & $1585.2(2)$ & $1584.7(3)$ & $1725.5(9)$ \\
\hline$Z$ value & 2 & 2 & 2 & 2 & 2 \\
\hline$D_{\text {calcd }}\left(\mathrm{Mg} \mathrm{m}^{-3}\right)$ & 1.765 & 1.785 & 1.801 & 1.805 & 1.749 \\
\hline$\mu(\mathrm{Mo} \mathrm{K} \alpha)\left(\mathrm{mm}^{-1}\right)$ & 1.770 & 2.114 & 2.234 & 2.373 & 2.428 \\
\hline$F(000)$ & 838 & 844 & 846 & 848 & 896 \\
\hline$\lambda(\mathrm{Mo} \mathrm{K} \alpha)(\AA)$ & 0.71073 & 0.71073 & 0.71073 & 0.71073 & 0.71073 \\
\hline Temperature (K) & 100 & 100 & 100 & 100 & 100 \\
\hline$R_{1}^{a}(I>2.00 \sigma(I))$ & 0.0308 & 0.0349 & 0.0325 & 0.0294 & 0.0378 \\
\hline $\mathrm{w} R_{2}^{b}(I>2.00 \sigma(I))$ & 0.0823 & 0.0947 & 0.0821 & 0.0807 & 0.0845 \\
\hline Goodness of fit & 1.055 & 1.082 & 1.061 & 1.073 & 1.072 \\
\hline Largest peak and hole $\left(\mathrm{e} \AA^{-3}\right)$ & $2.110,-1.090$ & $2.639,-1.439$ & $2.311,-1.227$ & $2.870,-1.409$ & $3.002,-1.530$ \\
\hline
\end{tabular}

${ }^{a} R_{1}=\Sigma|| F_{\mathrm{o}}|-| F_{\mathrm{c}}|| / \Sigma\left|F_{\mathrm{o}}\right| \cdot{ }^{b} \mathrm{w} R_{2}=\left\{\Sigma\left[\mathrm{w}\left(F_{\mathrm{o}}{ }^{2}-F_{\mathrm{c}}{ }^{2}{ }^{2}\right] / \Sigma\left[\mathrm{w}\left(F_{\mathrm{o}}{ }^{2}\right)^{2}\right]\right\}^{1 / 2}\right.$. 
(a)

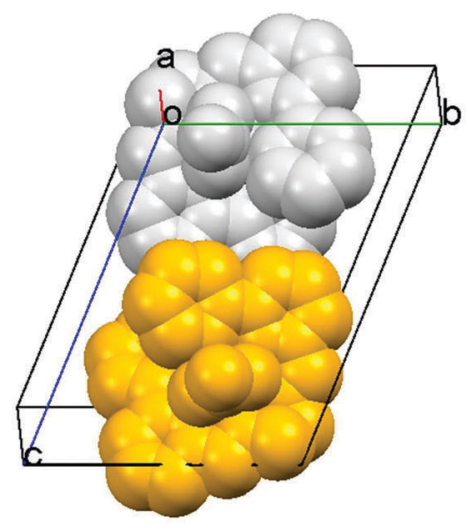

(b)

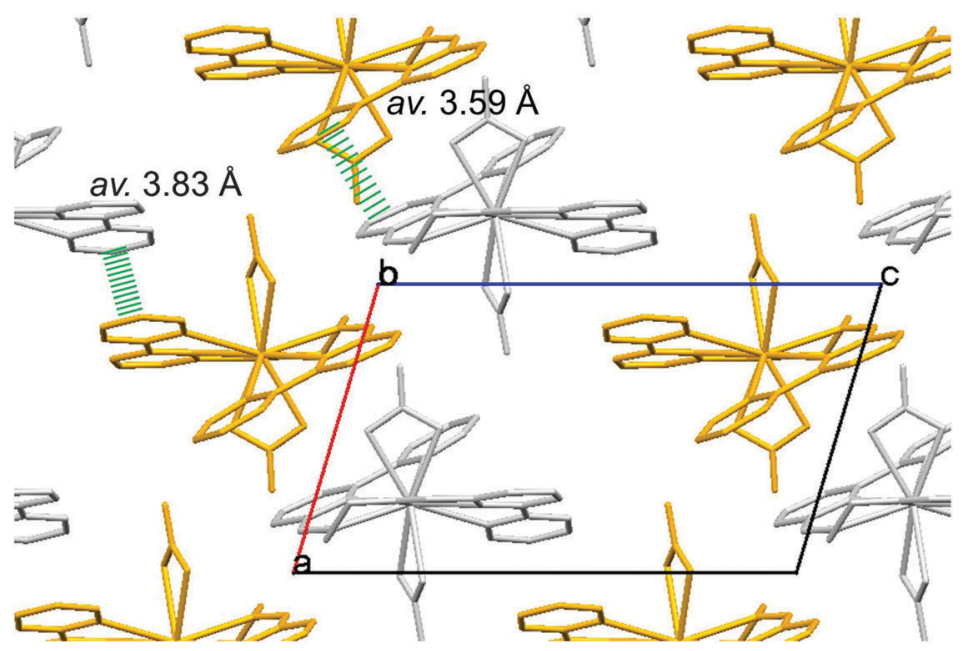

Fig. 3 (a) Two isomers in a unit cell of EuL, having left-handed (gold) and right-handed (silver) isomers obtained from X-ray single crystal structural analysis. (b) Molecular packing of EuL projected from along the $b$-axis. (Hydrogen atoms, $\mathrm{PF}_{6}{ }^{-}$and acetonitrile are omitted for clarity).

bands appear at 275, 315 and $330 \mathrm{~nm}$, respectively, in solution. This observation suggests that a series of $\mathbf{L n L}$ form molecular structures similar to those in solution and similar molecular arrangements in the solid state. ESI-TOF-MS spectra of these complexes in acetonitrile show a molecular ion for each $\mathrm{LnL}$ unit (Fig. S2, ESI $¥$ ). The shape of the broadened absorption band in the solid state compared with that in the solution is attributed to the intermolecular interaction as above mentioned. The electronic absorption bands of EuL are observed in acetonitrile, and the band at $330 \mathrm{~nm}$ can be ascribed as the lowest $\pi \pi^{*}$ transition experimentally. The $\pi \pi^{*}$ electronic absorption bands of NdL and HoL also appear at exactly corresponding positions of those of EuL (Fig. S6, ESI‡). Additionally, NdL or HoL shows sharp absorption bands originating from the ff-transitions of $\mathrm{Nd}^{\mathrm{III}}$ or $\mathrm{Ho}^{\mathrm{III}}$ as shown below.

To estimate the energy donor level of $\mathbf{L}$ of $\mathbf{L n} \mathbf{L}$, luminescence spectra of GdL have been examined, since a split upper f-level of $\mathrm{Gd}^{\mathrm{III}},{ }^{6} \mathrm{P}_{J}$, locates in the vacuum ultra violet region meaning that $\mathrm{Gd}^{\mathrm{III}}$ shows no ff emission. Emission bands of $\mathrm{GdL}$ are observed at $361(27500)$ and $c a .500 \mathrm{~nm}$ (as a broadened band $21700-16600 \mathrm{~cm}^{-1}$ ) mainly, at $\mathrm{rt}$ and $77 \mathrm{~K}$, respectively (Fig. 4c).

The former transition and latter are assigned to the fluorescence ${ }^{1} \mathrm{~S}$ and phosphorescence $\mathrm{T}$ band, respectively, localized on the bpy moiety of GdL. It means that the excited T level of $\mathbf{L}$ is suitable to act as an energy donor to $\mathrm{Eu}^{\mathrm{III}}$ or $\mathrm{Tb}^{\mathrm{III}}$. The complex, EuL or TbL (also, NdL), shows no $\pi \pi^{*}$ emissions, because the excited ligand-centred photon prevails for energy transfer to $\mathrm{Eu}^{\mathrm{III}}$ or $\mathrm{Tb}^{\mathrm{III}}$ relative to the $\pi \pi^{*}$ relaxations. It is notable that these $\mathrm{ff}$ emission properties of our present systems are unique, because the complexes have no $\pi \pi^{*}$ emission due to the efficient intramolecular energy transfer from $\mathbf{L}$ to $\mathbf{L n}^{\text {III }}$.

The luminescence spectra of EuL and TbL in acetonitrile and in the solid state are shown in Fig. 5. EuL in the solid state at $\mathrm{rt}$ shows the ff emission of the trivalent Eu ion at 580, 595,

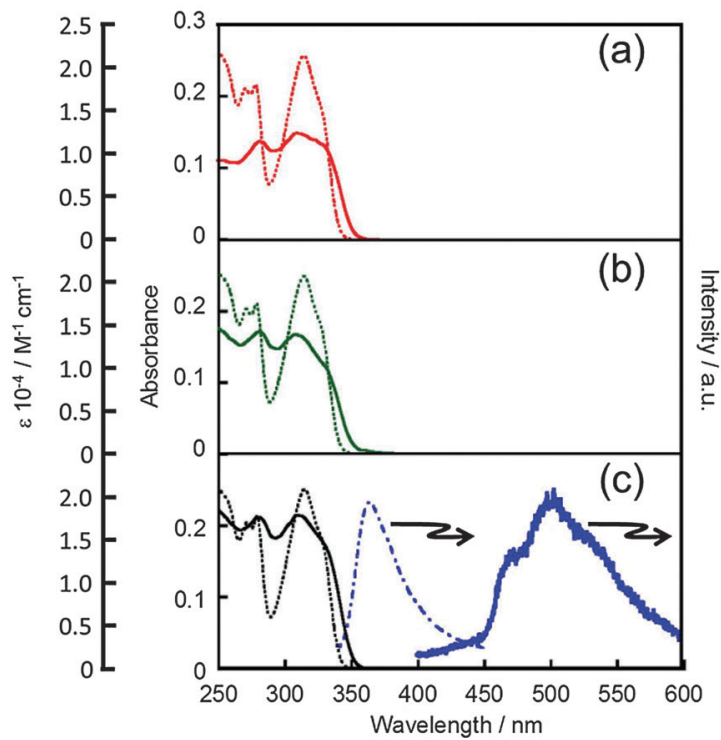

Fig. 4 Electronic spectra of EuL (a), TbL (b), and GdL (c) localized on the $\pi$ electronic systems. Absorption spectra in acetonitrile (dotted line) and in the solid state (solid line) use the left vertical scales; emission spectra in the solid state at $\mathrm{rt}$ (dotted-dash) and $77 \mathrm{~K}$ (thick) the right one $\left(\lambda_{\mathrm{ex}}=330 \mathrm{~nm}\right)$.

615,650 and $685 \mathrm{~nm}$, which is assigned to the ${ }^{5} \mathrm{D}_{0} \rightarrow{ }^{7} \mathrm{~F}_{0},{ }^{5} \mathrm{D}_{0} \rightarrow$ ${ }^{7} \mathrm{~F}_{1},{ }^{5} \mathrm{D}_{0} \rightarrow{ }^{7} \mathrm{~F}_{2},{ }^{5} \mathrm{D}_{0} \rightarrow{ }^{7} \mathrm{~F}_{3}$ and ${ }^{5} \mathrm{D}_{0} \rightarrow{ }^{7} \mathrm{~F}_{4}$ transitions, respectively. These bands of EuL appear at the same position at $77 \mathrm{~K}$. These corresponding bands are also observed at almost the same position in acetonitrile. Each excitation spectrum monitored at the ff emission band position reproduces well each electronic absorption spectrum assigned to the lowest excited state of $\mathbf{L}$ (Fig. S7, ESI $\$$ ).

Absolute luminescence quantum yields $Q_{\mathrm{Ln}}^{\mathrm{L}}$ and luminescence lifetimes $\tau_{\text {obs }}$ of EuL and TbL are estimated and the values are given in Table 2 . The $\tau_{\mathrm{obs}}$ values for ff-emissions of EuL in the solid state and in acetonitrile as well as TbL in the 

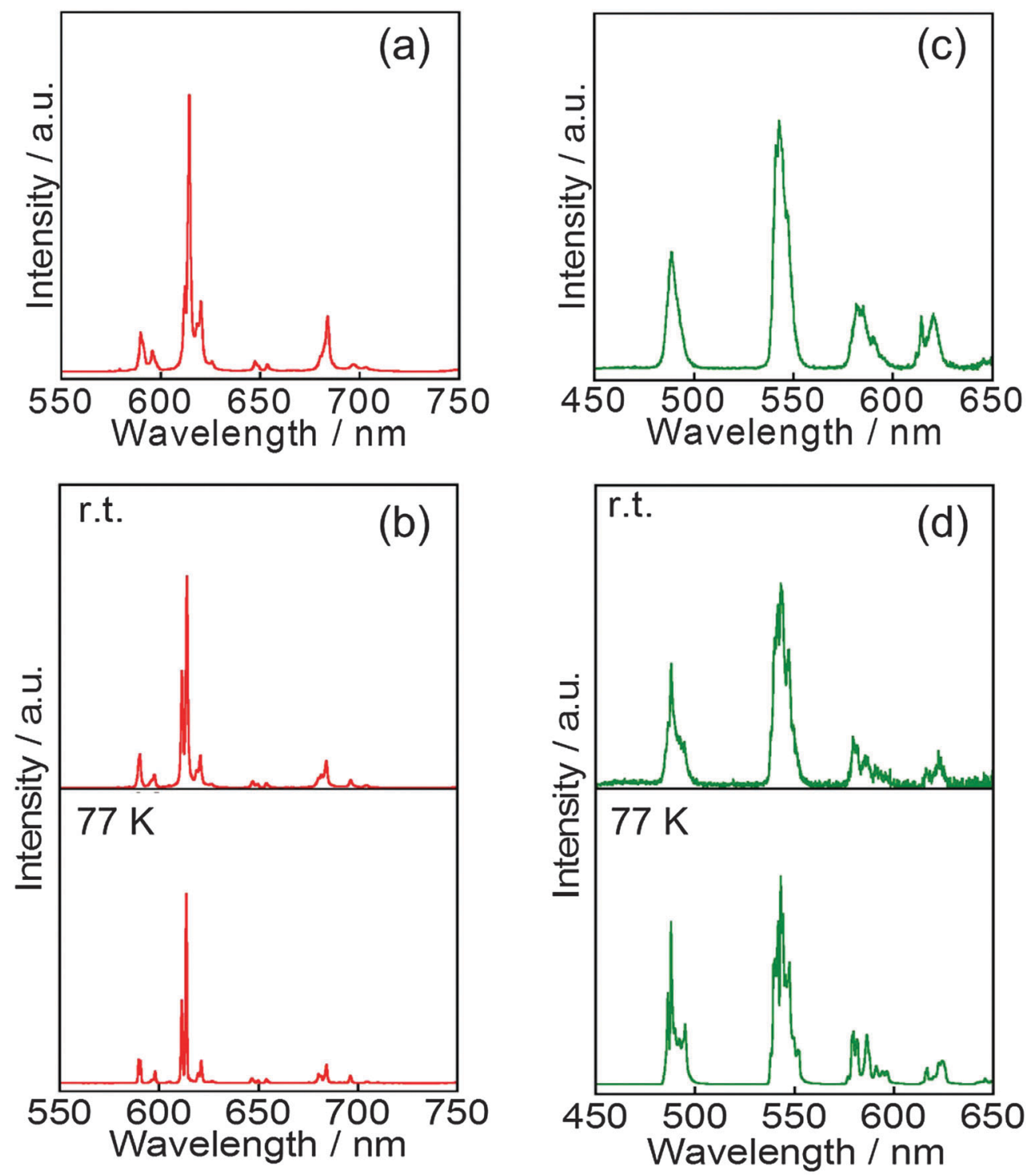

Fig. 5 Luminescence spectra of EuL ((a) and (b)) and TbL ((c) and (d)). (a) and (c) are in acetonitrile at rt, and (b) and (d) in the solid state at rt and $77 \mathrm{~K}\left(\lambda_{\mathrm{ex}}=330 \mathrm{~nm}\right.$ ).

Table 2 Luminescence lifetimes $\tau_{\text {obs }}$ (amplitude) and absolute luminescence quantum yields $Q_{\mathrm{Ln}}^{L}$ of ff emissions of $\operatorname{LnL}(\mathrm{Ln}=\mathrm{Eu}$ and $\mathrm{Tb})$

\begin{tabular}{|c|c|c|c|c|}
\hline & & Temp. & $\tau_{\text {obs }}[\mathrm{ms}](\mathrm{amp})$. & $Q_{\mathrm{Ln}}^{\mathrm{L}{ }^{a}}[\%]$ \\
\hline \multirow[t]{3}{*}{ EuL } & In the solid state & $\mathrm{rt}$ & $1.27(1.0)$ & $52.6( \pm 1.4)$ \\
\hline & & $77 \mathrm{~K}$ & $1.35(1.0)$ & $63.5( \pm 2.7)$ \\
\hline & In acetonitrile & $\mathrm{rt}$ & $1.55(1.0)$ & $12.0( \pm 0.5)$ \\
\hline \multirow[t]{2}{*}{$\mathrm{TbL}$} & In the solid state & $\mathrm{rt}$ & $\begin{array}{l}0.0153(0.96) \\
0.00234(0.04)\end{array}$ & $1.0( \pm 0.2)$ \\
\hline & In acetonitrile & $\begin{array}{l}77 \mathrm{~K} \\
\mathrm{rt}\end{array}$ & $\begin{array}{l}1.49(1.0) \\
\text { n.d. }\end{array}$ & $\begin{array}{l}91.5( \pm 1.4) \\
\approx 0\end{array}$ \\
\hline
\end{tabular}

${ }^{a}$ The values of Ln emission were based on the ligand excitation.

solid state at $77 \mathrm{~K}$ are closer to each other in the 1.27-1.55 ms range (Fig. S8, ESI $\ddagger$ ). The $Q_{\mathrm{Ln}}^{\mathrm{L}}$ values of EuL in the solid state preserve over $50 \%$ at ambient and low temperatures. Furthermore, the $Q_{\mathrm{Ln}}^{\mathrm{L}}$ value of EuL in acetonitrile is $12 \%$, which is not all that high while enough to discuss photoproperties even in solutions as same as those of other systems. ${ }^{39}$
It is generally known that the ff emissions of $\mathrm{Tb}^{\mathrm{III}}$ show thermal sensitivity, which is caused by the thermal equilibrium on the energy transfer pathway between the $\mathbf{T}$ level of $\mathbf{L}$ and the energy acceptor level of $\mathrm{Tb}^{\mathrm{III}} \cdot{ }^{40}$ It is noteworthy that $\mathrm{TbL}$ also leads to the efficient luminescence of TbL at $77 \mathrm{~K}$. Luminescence bands of TbL in acetonitrile appear at 490, 545, 587 and $623 \mathrm{~nm}$, which are assigned to the ${ }^{5} \mathrm{D}_{4} \rightarrow{ }^{7} \mathrm{~F}_{6},{ }^{5} \mathrm{D}_{4} \rightarrow{ }^{7} \mathrm{~F}_{5},{ }^{5} \mathrm{D}_{4} \rightarrow$ ${ }^{7} \mathrm{~F}_{4}$ and ${ }^{5} \mathrm{D}_{4} \rightarrow{ }^{7} \mathrm{~F}_{3}$ transitions, respectively (Fig. 5c). These band positions are almost the same as those in the solid state (Fig. 5d). Based on the estimation of $Q_{\mathrm{Ln}}^{\mathrm{L}}$ values of $\mathrm{TbL}$ (Table 2), the values at ambient temperature both in the solid state and in acetonitrile show negligible low values. While it is significant that at $77 \mathrm{~K}$ in the solid state, the $Q_{\mathrm{Ln}}^{\mathrm{L}}$ value of $\mathrm{TbL}$ drastically increases over $90 \%$. As far as we know, this value is the remarkably high value of quantum yields in Tb complexes, ${ }^{16 a, 41}$ and thus drastic thermal effect on the value is unusual. The energy relaxation mechanism of $\mathbf{T b} \mathbf{L}$ is shown in Fig. 6; the T level of $\mathbf{L}$ acts as an energy donor via intersystem crossing after the internal 


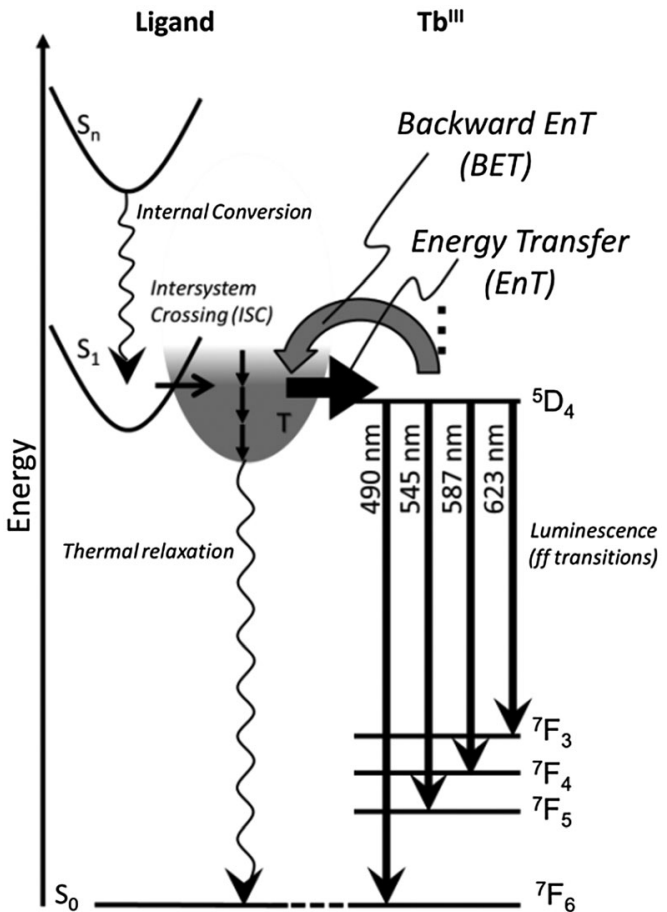

Fig. 6 Schematic representation of a plausible energy diagram of the electronic transitions of TbL.

conversion. That is, this thermal sensing effect of $\mathrm{TbL}$ is caused by the equilibrium between the emissive level of $\mathrm{Tb}^{\mathrm{III}}$ and the energy donating level of $\mathbf{L}$. Also, it is known that molecular oxygen acts as a quencher for the aromatic triplet excited state and similarly affects the lanthanide luminescence. ${ }^{42}$ Thus, the significantly low $Q_{\mathrm{Ln}}^{\mathrm{L}}$ value of $\mathrm{TbL}$ in acetonitrile might be affected by such oxygen molecule effects with thermal relaxation.

Emission and excitation spectra of NdL under various conditions are shown in Fig. 7 and Fig. S9 (ESI $\$$ ), respectively. The ff emission bands of $\mathrm{Nd}^{\mathrm{III}}$ appearing at 906, 1055 and $1345 \mathrm{~nm}$ are assigned to the ${ }^{4} \mathrm{~F}_{3 / 2} \rightarrow{ }^{4} \mathrm{I}_{9 / 2},{ }^{4} \mathrm{~F}_{3 / 2} \rightarrow{ }^{4} \mathrm{I}_{11 / 2}$ and ${ }^{4} \mathrm{~F}_{3 / 2} \rightarrow{ }^{4} \mathrm{I}_{13 / 2}$ transition, respectively. Former two transitions are divided into two or more by the Stark effect. The emission efficiency is quite low and it is difficult to estimate a quantitative value. However, it is found that the ligand $\mathbf{L}$ also acts as an energy donor and sensitizes the ff emissions of $\mathrm{Nd}^{\mathrm{III}}$ in the NIR region, since the

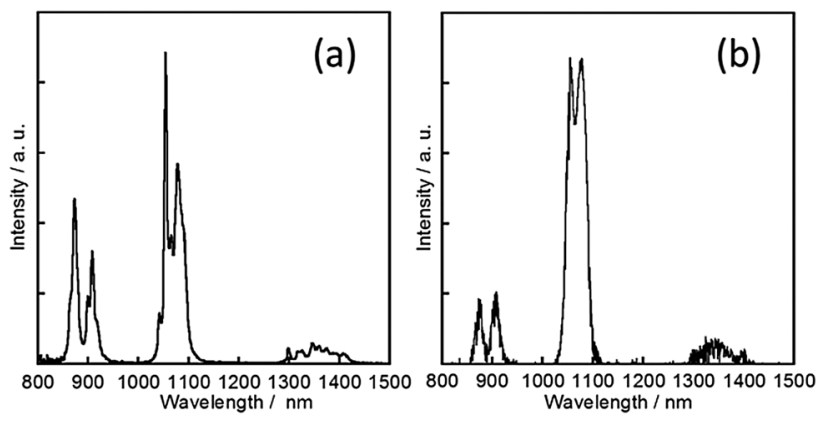

Fig. 7 Luminescence spectra of $\mathbf{N d L}$ (a) in the solid state and (b) in acetonitrile $\left(\lambda_{\mathrm{ex}}=330 \mathrm{~nm}\right)$. excitation spectrum shows good correspondence with the absorption bands of $\mathbf{L}$, not ff transitions of $\mathrm{Nd}^{\mathrm{III}}$ (Fig. 8a and b). In the solid state, the ff-absorption bands of $\mathrm{NdL}$ in the visible-NIR region appear at 468 (the ${ }^{4} \mathrm{I}_{9 / 2} \rightarrow{ }^{4} \mathrm{G}_{9 / 2}$ transition), $526\left({ }^{4} \mathrm{I}_{9 / 2} \rightarrow\right.$ $\left.{ }^{4} \mathrm{G}_{7 / 2}\right), 584\left({ }^{4} \mathrm{I}_{9 / 2} \rightarrow{ }^{4} \mathrm{G}_{5 / 2}\right), 626\left({ }^{4} \mathrm{I}_{9 / 2} \rightarrow{ }^{2} \mathrm{H}_{11 / 2}\right), 679\left({ }^{4} \mathrm{I}_{9 / 2} \rightarrow{ }^{4} \mathrm{~F}_{9 / 2}\right)$, $739\left({ }^{4} \mathrm{I}_{9 / 2} \rightarrow{ }^{2} \mathrm{H}_{9 / 2}\right), 800\left({ }^{4} \mathrm{I}_{9 / 2} \rightarrow{ }^{4} \mathrm{~S}_{3 / 2}\right)$ and $874\left({ }^{4} \mathrm{I}_{9 / 2} \rightarrow{ }^{4} \mathrm{~F}_{3 / 2}\right) \mathrm{nm}$. Corresponding ff-absorption bands of $\mathrm{NdL}$ in the solid state were clearly observed in acetonitrile.

HoL also shows the bands at $420\left({ }^{5} \mathrm{I}_{8} \rightarrow{ }^{5} \mathrm{G}_{5}\right), 450\left({ }^{5} \mathrm{I}_{8} \rightarrow\right.$ $\left.{ }^{5} \mathrm{G}_{6}\right), 472\left({ }^{5} \mathrm{I}_{8} \rightarrow{ }^{3} \mathrm{~K}_{8}\right), 486\left({ }^{5} \mathrm{I}_{8} \rightarrow{ }^{5} \mathrm{~F}_{2}\right), 537$ (overlap of ${ }^{5} \mathrm{I}_{8} \rightarrow{ }^{5} \mathrm{~F}_{4}$ and $\left.{ }^{5} \mathrm{I}_{8} \rightarrow{ }^{4} \mathrm{~S}_{2}\right)$ and $644\left({ }^{5} \mathrm{I}_{8} \rightarrow{ }^{5} \mathrm{~F}_{5}\right) \mathrm{nm}$ in acetonitrile and in the solid state (Fig. 8c and d). Due to small differences among the split f-levels of $\mathrm{Ho}^{\mathrm{III}}$, thermo-relaxation prevails over photorelaxation (luminescence).

Energy diagrams of the relaxation process of EuL, GdL and NdL are illustrated in Fig. S10 (ESI $\$$ ). The phosphorescence band position and width of GdL refer to the energy donor level against Ln ions. Since the structural analyses and the electronic absorption spectra localized on $\mathbf{L}$ for these complexes are in accordance with each other, it is considered that the donor level of $\mathbf{L}$ (triplet) of all complexes exists at the same energy level. The acceptor level of $\mathrm{Eu}^{\mathrm{III}}$ is more overlapped with the donor (Fig. S10(a), ESI $\ddagger$ ) than that of $\mathrm{Nd}^{\mathrm{III}}$ (Fig. S10(c), ESI $\ddagger$ ). These differences of EuL and $\mathrm{NdL}$ would affect the luminescence efficiencies.

\section{Conclusions}

The above presented new organic ligand forms stable Ln complexes with Nd, Eu, Gd, Tb and Ho. All of them formed a similar helical molecular structure in the crystalline state. Based on the above spectral results, TbL is preferred to thermal energy relaxation, since the thermal equilibrium between the energy donor and the acceptor level has been more preferential than the vibration effect of intermolecular interactions among neighbouring complexes. Furthermore, in solution, the ff-emission property of EuL is still present although it is less pronounced than in the solid state. This seems to be due to its stable molecular structure. Also NdL shows the respective ff-emission in the NIR region even in solution, despite its low efficiency probably due to its electronic structure. All complexes LnL with ff-emission properties do not show $\pi \pi^{*}$ luminescence, meaning that the photo-antenna acts efficiently.

\section{Experiments}

\section{Materials and synthesis}

Synthesis of ligand (L). Most reagents and spectra-grade solvents were used without further purification. Bipyridine-6-aldehyde was obtained by mixing 6-bromo-bipyridine $2.10 \mathrm{~g}$ ( $8.93 \mathrm{mmol}$; Isotech Laboratories, Inc.) and 1.6 $\mathrm{M} n$-hexane solution of $n$-butyl-lithium $6.80 \mathrm{ml}(10.9 \mathrm{mmol})$ in THF at $-80{ }^{\circ} \mathrm{C}$ for $30 \mathrm{~min}$, then stirred for $1 \mathrm{~h}$ after addition of dimethylformamide ${ }^{43}(0.670 \mathrm{mg}, 3.64 \mathrm{mmol}$, $40.8 \%$ yield). ${ }^{1} \mathrm{H}-\mathrm{NMR}$ (500.00 $\mathrm{MHz}, \mathrm{CDCl}_{3}$ ); $\delta 10.2$ (s, 1H), 8.72 (d, $\left.{ }^{3} J=4.1 \mathrm{~Hz}, 1 \mathrm{H}\right), 8.64(\mathrm{~m}, 1 \mathrm{H}), 8.57\left(\mathrm{~d},{ }^{3} J=8.2 \mathrm{~Hz}, 1 \mathrm{H}\right), 8.00$ (m, 2H), $7.86(\mathrm{~m}, 1 \mathrm{H}), 7.23(\mathrm{~m}, 2 \mathrm{H}), 7.38(\mathrm{~m}, 1 \mathrm{H})$. 

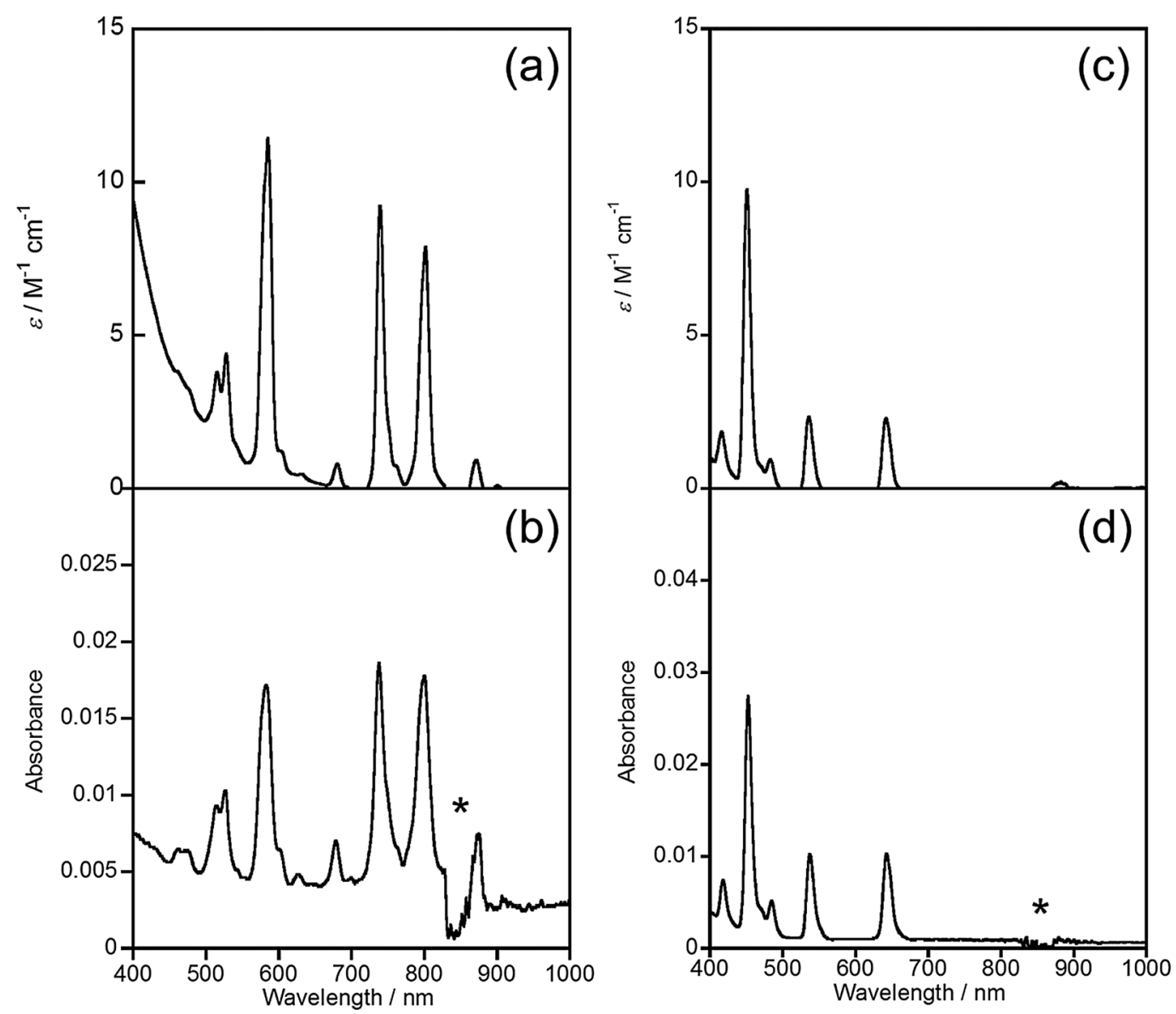

Fig. 8 Electronic absorption spectra of $\mathrm{NdL}((a)$ and (b)) and $\mathrm{HoL}((\mathrm{c})$ and (d)) in acetonitrile (upper) and in the solid state (bottom) (* due to apparatus).

The hexadentate ligand $\mathbf{L}$ was prepared by the reaction of bipyridine-6-aldehyde $200 \mathrm{mg}$ and ethylene-diamine (Kanto Chemicals Co., Inc.) in methanol $(160 \mathrm{mg}, 0.408 \mathrm{mmol}$, $74.9 \%$ yield). ${ }^{1} \mathrm{H}-\mathrm{NMR}\left(500.00 \mathrm{MHz}, \mathrm{CDCl}_{3}\right) ; \delta 8.64\left(\mathrm{~d},{ }^{3} \mathrm{~J}=\right.$ $4.1 \mathrm{~Hz}, 2 \mathrm{H}), 8.53(\mathrm{~s}, 2 \mathrm{H}), 8.41\left(\mathrm{dd},{ }^{3} J=7.8\right.$ and $\left.7.3 \mathrm{~Hz}, 4 \mathrm{H}\right), 8.04$ $\left(\mathrm{d},{ }^{3} \mathrm{~J}=6.9 \mathrm{~Hz}, 2 \mathrm{H}\right), 7.80\left(\mathrm{t},{ }^{3} \mathrm{~J}=7.8 \mathrm{~Hz}, 2 \mathrm{H}\right), 7.73(\mathrm{~m}, 2 \mathrm{H}), 7.23$ $(\mathrm{m}, 2 \mathrm{H}), 4.10(\mathrm{~s}, 4 \mathrm{H}) .{ }^{1} \mathrm{H}$-NMR chart of above compounds are shown in Fig. S1 (ESI ).

Synthesis procedure for $\mathbf{L n}$ complexes with $\mathbf{L}$. Lanthanide complexes with $\mathbf{L}, \mathrm{LnL}(\mathrm{Ln}=\mathrm{Nd}, \mathrm{Eu}, \mathrm{Gd}, \mathrm{Tb}$ and $\mathrm{Ho})$, were obtained by the reaction between $\mathbf{L}$ and lanthanide nitrate $n$-hydrate in methanol. For the crystallization, one nitrate anion was exchanged with $\mathrm{PF}_{6}{ }^{-}$by the $\mathrm{NH}_{4} \mathrm{PF}_{6}$ addition into their solution. The results of elemental analyses and ESI-TOF-MS (Fig. S2, ESI ) for the complexes are summarized below.

NdL. $50.4 \mathrm{mg}(0.115 \mathrm{mmol}) \mathrm{Nd}\left(\mathrm{NO}_{3}\right)_{3} \cdot 6 \mathrm{H}_{2} \mathrm{O}, 45.0 \mathrm{mg}$ $(0.115 \mathrm{mmol}) \mathbf{L}$ and $\mathrm{NH}_{3} \mathrm{PF}_{6} 18.7 \mathrm{mg}(0.115 \mathrm{mmol})$. Yield $77.2 \mathrm{mg}$ (80.1\%). Elemental analysis, calcd for $\left[\mathrm{Nd}(\mathbf{L})\left(\mathrm{NO}_{3}\right)_{2}\right]\left(\mathrm{PF}_{6}\right)$ $\left(\mathrm{C}_{24} \mathrm{H}_{20} \mathrm{~N}_{8} \mathrm{O}_{6} \mathrm{NdPF}_{6}\right)$; C 35.78, H 2.50, N 13.91; found; C 35.48, $\mathrm{H}$ 2.56, N 14.07; MS (ESI-TOF, acetonitrile); $\mathrm{m} / \mathrm{z}, 657.94$ $\left[\mathrm{M}-\mathrm{PF}_{6}\right]^{+}$(calcd 658.06).

EuL. $51.3 \mathrm{mg}(0.115 \mathrm{mmol}) \mathrm{Eu}\left(\mathrm{NO}_{3}\right)_{3} \cdot 6 \mathrm{H}_{2} \mathrm{O}, 45.0 \mathrm{mg}$ (0.115 mmol) $\mathbf{L}$ and $\mathrm{NH}_{3} \mathrm{PF}_{6} 18.7 \mathrm{mg}(0.115 \mathrm{mmol})$. Yield $51.3 \mathrm{mg}$
(55\%). Elemental analysis, calcd for $\left[\mathrm{Eu}(\mathbf{L})\left(\mathrm{NO}_{3}\right)_{2}\right]\left(\mathrm{PF}_{6}\right)$ $\left(\mathrm{C}_{24} \mathrm{H}_{20} \mathrm{~N}_{8} \mathrm{O}_{6} \mathrm{EuPF}_{6}\right)$; C 35.44, $\mathrm{H} 2.48, \mathrm{~N}$ 13.78; found; C 35.27, $\mathrm{H} 2.62, \mathrm{~N} 13.70$; MS (ESI-TOF, acetonitrile); $m / z$, $668.97\left[\mathrm{M}-\mathrm{PF}_{6}{ }^{-}\right]^{+}$ (calcd 669.07).

GdL. $121 \mathrm{mg}(0.270 \mathrm{mmol}) \mathrm{Gd}\left(\mathrm{NO}_{3}\right)_{3} \cdot 6 \mathrm{H}_{2} \mathrm{O}, 105.6 \mathrm{mg}$ $(0.270 \mathrm{mmol}) \mathbf{L}$ and $\mathrm{NH}_{3} \mathrm{PF}_{6} 44.0 \mathrm{mg}(0.270 \mathrm{mmol})$. Yield $58.4 \mathrm{mg}(31 \%)$. Elemental analysis, calcd for $\left[\mathrm{Gd}(\mathbf{L})\left(\mathrm{NO}_{3}\right)_{2}\right]\left(\mathrm{PF}_{6}\right)$ $\left(\mathrm{C}_{24} \mathrm{H}_{20} \mathrm{~N}_{8} \mathrm{O}_{6} \mathrm{GdPF}_{6}\right)$; C 35.21, $\mathrm{H} 2.46, \mathrm{~N}$ 13.69; found; C 35.12, $\mathrm{H} 2.68, \mathrm{~N} 13.62$; MS (ESI-TOF, acetonitrile); $m / z, 674.06\left[\mathrm{M}-\mathrm{PF}_{6}{ }^{-}\right]^{+}$ (calcd 674.08).

TbL. $52.1 \mathrm{mg}(0.115 \mathrm{mmol}) \mathrm{Tb}\left(\mathrm{NO}_{3}\right)_{3} \cdot 6 \mathrm{H}_{2} \mathrm{O}, 45.0 \mathrm{mg}$ (0.115 mmol) $\mathbf{L}$ and $\mathrm{NH}_{3} \mathrm{PF}_{6} 18.7 \mathrm{mg}(0.115 \mathrm{mmol})$. Yield 68.3 $\mathrm{mg}(62 \%)$. Elemental analysis, calcd for $\left[\mathrm{Tb}(\mathbf{L})\left(\mathrm{NO}_{3}\right)_{2}\right]\left(\mathrm{PF}_{6}\right)$ $\left(\mathrm{C}_{24} \mathrm{H}_{20} \mathrm{~N}_{8} \mathrm{O}_{6} \mathrm{TbPF}_{6}\right)$; C 35.14, H 2.46, N 13.66; found; C 35.26, $\mathrm{H}$ 2.70, N 13.50; MS (ESI-TOF, acetonitrile); $\mathrm{m} / z, 675.02$ $\left[\mathrm{M}-\mathrm{PF}_{6}{ }^{-}\right]^{+}$(calcd 675.08).

HoL. $50.7 \mathrm{mg}(0.115 \mathrm{mmol}) \mathrm{Ho}\left(\mathrm{NO}_{3}\right)_{3} \cdot 5 \mathrm{H}_{2} \mathrm{O}, 45.0 \mathrm{mg}$ $(0.115 \mathrm{mmol}) \mathrm{L}$ and $\mathrm{NH}_{3} \mathrm{PF}_{6} 18.7 \mathrm{mg}(0.115 \mathrm{mmol})$. Yield $79.4 \mathrm{mg}$ (80.4\%). Elemental analysis, calcd for $\left[\mathrm{Ho}(\mathbf{L})\left(\mathrm{NO}_{3}\right)_{2}\right]\left(\mathrm{PF}_{6}\right) \cdot \mathrm{H}_{2} \mathrm{O}$ $\left(\mathrm{C}_{24} \mathrm{H}_{22} \mathrm{~N}_{8} \mathrm{O}_{7} \mathrm{HoPF}_{6}\right)$; C 34.14, $\mathrm{H} 2.63, \mathrm{~N}$ 13.27; found; C 33.95, $\mathrm{H}$ 2.93, N 13.19; MS (ESI-TOF, acetonitrile); $m / z, 680.97\left[\mathrm{M}-\mathrm{PF}_{6}{ }^{-}\right]^{+}$ (calcd 681.08). 


\section{Instrumentation}

Electronic absorption and luminescence spectra were recorded on a Shimadzu UV3101PC and a Horiba Jobin-Ybon Fluorolog 3-22. The NIR emission was detected by the attachment C1452AU on the above apparatus. The emission decay curves were measured using a Quantaurus-Tau C11367-12 (Hamamatsu Photonics K. K.) excited by a Xenon flash lamp with a band-path filter $\left(\lambda_{\mathrm{ex}}=340 \mathrm{~nm}\right)$. The fluorescence quantum yields were measured using The C9920-02 Absolute PL Quantum Yield Measurement System (Hamamatsu Photonics K. K.). ${ }^{44}$

Electrospray ionization time of flight (ESI-TOF) mass spectra and elemental analyses for CHN were recorded on a LCT ESI-TOF spectrometer (Micromass), and MICRO CORDER (J-SCIENCE LAB), respectively.

\section{X-ray crystallography}

X-ray structural data for $\mathrm{LnL}(\mathrm{Ln}=\mathrm{Nd}, \mathrm{Eu}, \mathrm{Gd}, \mathrm{Tb}$ and Ho) were collected on a Bruker Smart APEX-II CCD diffractometer equipped with graphite monochromated Mo $\mathrm{K} \alpha$ radiation at $100 \mathrm{~K}$. The data were collected to a maximum $2 \mathrm{~h}$ value of $55^{\circ}$ and processed using the Bruker Apex2 software package. ${ }^{45}$ The structures were solved by direct methods and refined by full-matrix least-squares calculations using SHELX-97. ${ }^{46}$ All non-hydrogen atoms were refined anisotropically, and all hydrogen atoms were located at idealized positions. Summaries of the fundamental crystal data and experimental parameters used to determine the structures of complexes LnL are given in ESI. $\neq$ CCDC 919427 for EuL, 919428 for GdL, 919429 for HoL, 919430 for NdL and 919431 for TbL.

\section{Acknowledgements}

We thank Prof. Takashi Kato (the University of Tokyo) and Prof. Wolfgang Linert (Technical University of Vienna) for their kind discussion. Prof. Yoshiki Ohgo (Teikyo University) could help to refine structural analyses of a series of single crystals. Prof. Yasuteru Shigeta (Osaka University) could suggest important points of view for the energy diagram of electronic transitions. Dr Isao Takahashi, Yu Yoshimura and Sae Enomoto (AGU) also helped to synthesize the related complexes. Prof. Hideki Masuda, Prof. Tomohiro Ozawa and Dr Tomohiko Inomata (Nagoya Institute of Technology) could kindly help to measure ESI-TOF-MS in solutions. This work was partly supported by the Grants-in-Aid for Young Scientists A (No. 20685011), Scientific Research on Innovative Areas of "Fusion Materials: Creative Development of Materials and Exploration of Their Function through Molecular Control (Area Number: 2206)" (No. 23107528 and 25107730), Challenging Exploratory Research (No. 23656544) and The High-Tech Research Centre Project for Private Universities with a matching fund subsidy from MEXT.

\section{Notes and references}

1 (a) M. A. Katkova and M. N. Bochkarev, Dalton Trans., 2010, 39, 6599; (b) G. Zucchi, Int. J. Inorg. Chem., 2011,
2011, 92435; (c) J. Kido and Y. Okamoto, Chem. Rev., 2002, 102, 2357.

2 J. F. Wang, R. Y. Wang, J. Yang, Z. P. Zheng, M. D. Carducci, T. Cayou, N. Pwyghambarian and G. E. Jabbour, J. Am. Chem. Soc., 2001, 123, 6179.

3 Z. Chen, F. Ding, F. Hao, M. Guan, Z. Bian, B. Ding and C. Huang, New J. Chem., 2010, 34, 487.

4 S.-J. Yeh, M.-F. Wu, C.-T. Chen, Y.-H. Song, Y. Chi, M.-H. Ho, S.-F. Hsu and C.-H. Chen, Adv. Mater., 2005, 17, 285.

5 H. Xin, F. Y. Li, M. Shi, Z. Q. A. Bian and C. H. Huang, J. Am. Chem. Soc., 2003, 125, 7166; M. A. Katkova, A. P. Pushkarev, T. V. Balashova, A. N. Konev, G. K. Fukin, S. Y. Ketkov and M. N. Bochkarev, J. Mater. Chem., 2011, 21, 16611.

6 S. F. Wuister, C. Donegá and A. Meijerink, Phys. Chem. Chem. Phys., 2004, 6, 1633.

7 B. M. van der Ende, L. Aarts and A. Meijerink, Phys. Chem. Chem. Phys., 2009, 11, 11081.

8 (a) R. Pal, D. Parker and L. C. Costello, Org. Biomol. Chem., 2009, 7, 1525; (b) G.-L. Law, R. Pal, L. O. Palsson, D. Parker and K.-L. Wong, Chem. Commun., 2009, 7321; (c) D. G. Smith, R. Pal and D. Parker, Chem.-Eur. J., 2012, 18, 11604; (d) P. K. Senanayake, D. Parker and J. A. G. Williams, J. Chem. Soc., Perkin Trans. 2, 1998, 2129.

9 C. P. Montgomery, B. S. Murray, E. J. New, R. Pal and D. Parker, Acc. Chem. Res., 2009, 42, 925.

10 (a) S. Shinoda, K. Terada, M. Eiraku Masaki, Y. Kataoka and H. Tsukube, New J. Chem., 2012, 36, 1545; (b) H. Miyake and H. Tsukube, Chem. Soc. Rev., 2012, 41, 6977; (c) K. Ariga, H. Ito, J. P. Hill and H. Tsukube, Chem. Soc. Rev., 2012, 41, 5800 .

11 (a) J. W. Walton, A. Bourdolle, S. J. Butler, M. Soulie, M. Deldianco, B. K. McMahon, R. Pal, H. Puschmann, J. M. Zwier, L. Lamarque, O. Maury, C. Andraud and D. Parker, Chem. Commun., 2013, 49, 1600; (b) R. A. Poole, G. Bobba, M. J. Cann, J. C. Frias, D. Parker and R. D. Peacock, Org. Biomol. Chem., 2005, 3, 1013.

12 (a) T. Gunnlaugsson, J. P. Leonard, K. Sénéchal and A. J. Harte, J. Am. Chem. Soc., 2003, 125, 12062; (b) O. Kotova, S. Comby and T. Gunnlaugsson, Chem. Commun., 2011, 47, 6810.

13 (a) F. S. Richardson, Chem. Rev., 1982, 82, 541; (b) L. Armelao, S. Quici, F. Barigelletti, G. Accorsi, G. Bottaro, M. Cavazzini and E. Tondello, Coord. Chem. Rev., 2010, 254, 487.

14 (a) S. V. Eliseeva and J.-C. Bünzli, Chem. Soc. Rev., 2010, 39, 189; (b) J.-C. Bünzli and C. Piguet, Chem. Soc. Rev., 2005, 34, 1048.

15 (a) M. Brebol, U. Kynast and C. Ronda, Adv. Mater., 1991, 3, 361; (b) N. Filipescu, G. W. Mushrush, C. R. Hurt and N. McAvoy, Nature, 1966, 211, 960; (c) S. Sato and M. Wada, Bull. Chem. Soc. Jpn., 1970, 43, 1955.

16 (a) M. Hasegawa, A. Nakao, M. Masui, T. Tamura, D. Suzuki, W. Linert, Y. Fukuda and T. Hoshi, Chem. Phys., 2001, 269, 323; (b) M. Hasegawa, A. Ishii, T. Yamazaki, S. Kishi and I. Yamazaki, Chem. Lett., 2005, 1418; (c) M. Hasegawa, A. Ishii and S. Kishi, J. Photochem. Photobiol., A, 2006, 178, 220 . 
17 (a) J.-C. G. Bünzli, A.-S. Chauvin, H. K. Kim, E. Deiters and S. V. Eliseeva, Coord. Chem. Rev., 2010, 254, 2623; (b) A. Beeby, L. M. Bushby, D. Maffeo and J. A. G. Williams, J. Chem. Soc., Dalton Trans., 2002, 48; (c) G. Adachi, N. Imanaka and S. Tamura, J. Rare Earths, 2010, 28, 843.

18 (a) S. Quici, G. Marzanni, A. Forni, G. Accorsi and F. Barigelletti, Inorg. Chem., 2004, 43, 1294; (b) O. L. Malta, H. F. Brito, J. F. S. Menezes, F. R. Gonçalves e Silva, C. de Mello Donegá and S. Alves Jr., Chem. Phys. Lett., 1998, 282, 233; (c) E. G. Moore, J. Jocher, J. Xu, E. J. Werner and K. N. Raymond, Inorg. Chem., 2007, 46, 5468; (d) R. Zong, G. Zhang, S. V. Eliseeva, J.-C. G. Bünzli and R. P. Thummel, Inorg. Chem., 2010, 49, 4657; (e) J.-F. Lemonnier, L. Guénée, C. Beuchat, T. A. Wesolowski, P. Mukherjee, D. H. Waldeck, K. A. Gogick, S. Petoud and C. Piguet, J. Am. Chem. Soc., 2011, 113, 16219.

19 (a) S. Quici, M. Cavazzini, G. Marzanni, G. Accorsi, N. Armaroli, B. Ventura and F. Barigelletti, Inorg. Chem., 2005, 44, 529; (b) S. I. Klink, G. A. Hebbink, L. Grave, P. G. B. O. Alink, F. C. J. M. van Veggel and M. H. V. Werts, J. Phys. Chem. A, 2002, 106, 3681; (c) S. Lis, Z. Hnatejko, P. Barczynski and M. Elbanowski, J. Alloys Compd., 2002, 344, 70.

20 V.-M. Mukkala and J. J. Kankare, Helv. Chim. Acta, 1992, $75,1578$.

21 A. Bourdolle, M. Allali, J.-C. Mulatier, B. Le Guennic, J. M. Zwier, P. L. Baldeck, J.-C. G. Bünzli, C. Andraud, L. Lamarque and O. Maury, Inorg. Chem., 2011, 50, 4987.

22 Z. Pan, G. Jia, C.-K. Duan, W.-Y. Wong, W.-T. Wong and P.-A. Tanner, Eur. J. Inorg. Chem., 2011, 637.

23 N. M. Shavaleev, S. V. Eliseeva, R. Scopelliti and J.-C. Bünzli, Chem.-Eur. J., 2009, 15, 10790.

24 K. Miyata, T. Nakagawa, R. Kawakami, Y. Kita, K. Sugimoto, T. Nakashima, T. Harada, T. Kawai and Y. Hasegawa, Chem.-Eur. J., 2011, 17, 521.

25 L. J. Charbonnière, N. Wiebel, P. Retailleau and R. Ziessel, Chem.-Eur. J., 2007, 13, 346.

26 C. Butler, S. Goetz, C. M. Fitchett, P. E. Kruger and T. Gunnlaugsson, Inorg. Chem., 2011, 50, 2723.

27 S. Quici, M. Cavazzini, G. Marzanni, G. Accorsi, N. Armaroli, B. Ventura and F. Barigelletti, Inorg. Chem., 2005, 44, 529.

28 C. Kachi-Terajima, K. Yanagi, T. Kazuki, T. Kitazawa and M. Hasegawa, Dalton Trans., 2011, 40, 2249.

29 Y. Hasegawa, R. Hieda, K. Miyata, T. Nakagawa and T. Kawai, Eur. J. Inorg. Chem., 2011, 4978.

30 J. L. Bender and C. L. Fraser, ACS Symposium Series "Chromogenic Phenomena in Polymers", 2005, ch. 18, vol. 888, p. 233.

31 (a) Y.-L. Huang, M.-Y. Huang, T.-H. Chan, B.-C. Chang and K.-H. Lii, Chem. Mater., 2007, 19, 3232; (b) B. D. Chandler, J. O. Yu, D. T. Cramb and G. K. H. Shimizu, Chem. Mater., 2007, 19, 4467.

32 (a) A. Kobayashi, H.-C. Chang, Y. Fukuzawa and M. Kato, Inorg. Chem., 2012, 51, 7508; (b) T. K. Maji, G. Mostafa, H.-C. Chang and S. Kitagawa, Chem. Commun., 2005, 2436; (c) L. J. Charbonnière, R. Ziessel, M. Montalti, L. Prodi, N. Zaccheroni, C. Boehme and G. Wipff, J. Am. Chem. Soc., 2002, 124, 7779.

33 T. Kajiwara, M. Hasegawa, A. Ishii, K. Katagiri, M. Baater, S. Takaishi, N. Iki and M. Yamashita, Eur. J. Inorg. Chem., 2008, 5565.

34 L. Charbonnière, S. Mameri, P. Kadjane, C. Platas-Iglesias and R. Ziessel, Inorg. Chem., 2008, 47, 3748.

35 (a) E. C. Constable, R. Chotalia and D. A. Tocher, J. Chem. Soc., Chem. Commun., 1992, 771; (b) M. H. W. Lam, D. Y. K. Lee, S. S. M. Chiu, K. W. Man and W. T. Wong, Eur. J. Inorg. Chem., 2000, 1483.

36 (a) R. Zong and R. P. Thummel, Inorg. Chem., 2005, 44, 5984; (b) L. Aboshyan-Sorgho, H. Nozary, A. Aebischer, J.-C. G. Bünzli, P.-Y. Morgantini, K. R. Kittilstved, A. Hauser, S. V. Eliseeva, S. Petoud and C. Piguet, J. Am. Chem. Soc., 2012, 134, 12675; (c) S. Petoud, J.-C. G. Bünzli, F. Renaud, C. Piguet, K. J. Schenk and G. Hopfgartner, Inorg. Chem., 1997, 36, 5750.

37 (a) E. C. Constable, G. Zhang, C. E. Housecroft, M. Neuburger and J. A. Zampese, CrystEngComm, 2010, 12, 3724; (b) E. C. Constable, G. Zhang, C. E. Housecroft, M. Neuburger and S. Schaffner, Dalton Trans., 2009, 8165; (c) E. C. Constable, G. Zhang, C. E. Housecroft and J. A. Zampese, Dalton Trans., 2010, 39, 5332; (d) E. C. Constable, G. Zhang, C. E. Housecroft, M. N. Neuburger and J. A. Zampese, Eur. J. Inorg. Chem., 2010, 2000.

38 For instance, (a) G. Zucchi, V. Murugesan, D. Tondelier, D. Aldakov, T. Jeon, F. Yang, P. Thuéry, M. Ephritikhine and B. Geffroy, Inorg. Chem., 2011, 50, 4851; (b) S. Petoud, S. M. Cohen, J.-C. G. Bünzli and K. N. Raymond, J. Am. Chem. Soc., 2003, 125, 13324.

39 (a) D. Parker and J. A. G. Williams, J. Chem. Soc., Dalton Trans., 1996, 3613; (b) S. Katagiri, Y. Tsukahara, Y. Hasegawa and Y. Wada, Bull. Chem. Soc. Jpn., 2007, 8, 1492; (c) Y. Zheng, C. Tan, G. P. C. Drummen and Q. Wang, Spectrochim. Acta, Part A, 2012, 96, 387; (d) Y. Cui, H. Xu, Y. Yue, Z. Guo, J. Yu, Z. Chen, J. Gao, Y. Yang, G. Qian and B. Chen, J. Am. Chem. Soc., 2012, 134, 3979; (e) J. Andres and A.-S. Chauvin, Inorg. Chem., 2011, 50, 10082.

40 (a) E. Brunet, O. Juanes, R. Sedano and J.-C. Rodríguez-Ubis, Photochem. Photobiol. Sci., 2002, 1, 613; (b) M. Starck, P. Kadjane, E. Bois, B. Darbouret, A. Incamps, R. Ziessel and L. J. Charbonnière, Chem.-Eur. J., 2011, 17, 9164; (c) A. R. Ramya, M. L. P. Reddy, A. H. Cowley and K. V. Vasudevan, Inorg. Chem., 2010, 49, 2407; (d) S. Biju, M. L. P. Reddy, A. H. Cowley and K. V. Vasudevan, J. Mater. Chem., 2009, 19, 5179; (e) A. P. S. Samuel, E. G. Moore, M. Melchior, J. Xu and K. N. Raymond, Inorg. Chem., 2008, 47, 7535.

41 D. Parker and J. A. G. Williams, Chem. Commun., 1998, 245; and their in.

42 F. R. Heirtzler, M. Neuburger, M. Zehnder and E. C. Constable, Liebigs Ann./Recl., 1997, 297.

43 (a) Y. Kawamura, H. Sasabe and C. Adachi, Jpn. J. Appl. Phys., 2004, 43, 7729; (b) K. Suzuki, A. Kobayashi, S. Kaneko, 
K. Takehira, T. Yoshihara, H. Ishida, Y. Shiina, S. Oishi and S. Tobita, Phys. Chem. Chem. Phys., 2009, 11, 9850; (c) A. Kobayashi, K. Suzuki, T. Yoshihara and S. Tobita, Chem. Lett., 2010, 39, 282; (d) M. Hasegawa, A. Ishii, K. Furukawa and H. Ohtsu, J. Photopolym. Sci. Technol., 2008, 21, 333; (e) M. Hasegawa, S. Kunisaki, H. Ohtsu and W. Franz, Monatsh. Chem., 2009, 140, 751.
44 SMART, SAINT, XPREP and SADABS, Bruker AXS Inc., Madision, Wisconsin, 2004.

45 (a) G. M. Sheldrick, Acta Crystallogr., Sect. A: Fundam. Crystallogr., 2008, 64, 112-122; (b) G. M. Sheldrick, SHELXS-97, University of Göttingen, Göttingen, 1997; (c) G. M. Sheldrick, SHELX-97, University of Göttingen, Göttingen, 1997. 